\title{
PENINGKATAN HASIL BELAJAR PKN POKOK BAHASAN MEMAHAMI KEBEBASAN BERORGANISASI DENGAN MENGGUNAKAN METODE STUDI LAPANGAN
}

\author{
Moh.Nuril Hudha ${ }^{1)}$ \\ 1) Universitas Abdurachman Saleh Situbondo \\ airvillageband@gmail.com
}

\begin{abstract}
ABSTRAK: Mata pelajaran PKN dengan pokok bahasan memahami kebebasan berorganisasi ini adalah materi yang cukup sulit, hal ini dilihat dari partisipasi siswa dan hasil tes awal pembelajaran yang masih rendah. Tingkat keberhasilan proses belajar mengajar ditunjukkan oleh penguasaan materi oleh siswa. Tingkat penguasaan materi oleh siswa dapat diketahui dari hasil ulangan yang diberikan oleh guru. Hasil ulangan yang dilaksanakan peneliti di kelas V semester genap tahun pelajaran 2019-2020 berdasarkan data yang diperoleh dari hasil ulangan mata pelajaran Pendidikan kewarganegaraan (PKN) tingkat keberhasilannya 55\% atau dari 20 siswa. Penggunaan PTK sebagai salah satu penelitian untuk meningkatkan hasil belajar siswa dengan dua siklus. Pelaksanaan siklus I ini direncanakan peneliti dan observer setelah melihat hasil pembelajaran sebelumnya yang hanya mencapai $55 \%$ tingkat keberhasilan. Siklus I ini dilaksanakan pada tanggal 4 Mei 2020. Setelah dilaksanakan proses pembelajaran dengan dengan metode Studi Lapangan ternyata hasil belajar siswa cukup baik yaitu $75 \%$ siswa sudah mendapatkan nilai diatas KKM. Pada siklus II Hasil belajar siswa kelas V SDN 2 Duwet dari 20 siswa, siswa yang mendapat nilai diatas KKM berjumlah 18 orang $(90 \%)$ sesudah dilaksanakan tindakan perbaikan pembelajaran siklus II maka hasil belajar siswa pada siklus II ini sudah melampaui standar minimal ketuntasan klasikal yaitu $70 \%$.
\end{abstract}

Kata kunci : Penelitian Tindakan Kelas, Hasil Belajar, Organisasi, Studi lapangan

ABSTRACT: The PKN subject with the subject of understanding freedom of organization is quite difficult material, this can be seen from student participation and the low initial results of learning. The success rate of the teaching and learning process is shown by the students' mastery of the material. The level of mastery of the material by students can be seen from the results of the tests given by the teacher. The results of the tests carried out by researchers in class $V$ even semester of the 2019-2020 academic year were based on data obtained from the results of the Civics Education (PKN) subject, the success rate was 55\% or from 20 students. The use of CAR as one of the studies to improve student learning outcomes in two cycles. The implementation of cycle I was planned by researchers and observers after seeing the results of previous learning which only reached a 55\% success rate. Cycle I was held on May 4, 2020. After the learning process was carried out using the Field Study method, it turned out that the student learning outcomes were quite good, namely $75 \%$ of students had already scored above the KKM. In cycle II the learning outcomes of students in grade V SDN 2 Duwet from 20 students, students who scored above the KKM amounted to 18 people (90\%) after the implementation of corrective action for learning cycle II, the student learning outcomes in cycle II have exceeded the minimum standard of classical completeness, namely $70 \%$.

Keywords: Classroom Action Research, Learning Outcomes, Organization, Field Study

\section{PENDAHULUAN}

Sekolah Dasar merupakan lembaga pendidikan pertama yang memiliki peranan penting dalam dunia pendidikan,agar dapat memberikan dasar terhadap pendidikan selanjutnya. Mata pelajaran Pendidikan kewarganegaraan (PKN) merupakan mata pelajaran yang sangat penting diajarkan di sekolah, baik di sekolah negeri maupun 
swasta. Mata pelajaran Pendidikan kewarganegaraan (PKN) sangat memerlukan perhatian yang serius agar segala kesulitan dan permasalahannya dapat teratasi, baik dari metode, alat peraga, media, sumber belajar maupun dari faktor guru dan siswa dapat teratasi.

Keberhasilan proses belajar mengajar di sekolah banyak dipengaruhi oleh faktor guru dan siswa. Kompetensi guru dalam menjalankan aktifitas belajar mengajar merupakan salah satu faktor yang menentukan motivasi dan keberhasilan siswa dalam belajar. Guru dituntut untuk memiliki kemampuan pengetahuan, pengelolaan kelas dan pengunaan metode pembelajaran yang tepat supaya dapat mencapai keberhasilan yang maksimal dalam proses kegiatan belajar mengajar.

Sekolah tempat penelitian, sangat jauh dari keramaian kota. terletak di daerah pingiran Kecamatan Panarukan, dengan kondisi alam dekat dengan laut. Masyarakat di sekitar sekolah maupun wali murid masih kurang peduli terhadap pendidikan, sehingga mempengaruhi terhadap kehadiran siswa dan pengetahuan siswa. Adapun kondisi sekolah SDN 2 Duwet memiliki 6 ruang kelas untuk proses belajar mengajar, walaupun 3 ruang kelas dalam kondisi rusak, tetapi masih tetap ditempati untuk proses belajar mengajar;Jumlah siswa kelas I - VI = 127 anak. Jumlah guru/tenaga pengajar 2 orang guru kelas, 1 orang guru Pendidikan Agama dan 1 orang Kepala Sekolah. Fasilitas penunjang baik buku pelajaran, alat peraga, maupun media pembelajaran kurang memadai. Dengan kondisi kekurangan tenaga pengajar, ruang kelas yang rusak dan fasilitas penunjang yang kurang memadai sangatlah berpengaruh untuk mencapai keberhasilan dalam melaksanakan kegiatan belajar mengajar. Pemilihan strategi dan metode pembelajaran serta sumber belajar yang tepat akan sangat membantu siswa dan guru dalam melaksanakan proses belajar mengajar untuk mencapai keberhasilan yang maksimal.

Mata pelajaran PKN dengan pokok bahasan memahami kebebasan berorganisasi ini adalah materi yang cukup sulit, hal ini dilihat dari partisipasi siswa dan hasil tes awal pembelajaran yang masih rendah. Tingkat keberhasilan proses belajar mengajar ditunjukkan oleh penguasaan materi oleh siswa. Tingkat penguasaan materi oleh siswa dapat diketahui dari hasil ulangan yang diberikan oleh guru. Hasil ulangan yang dilaksanakan peneliti di kelas V semester genap tahun pelajaran 2019-2020 berdasarkan data yang diperoleh dari hasil ulangan mata pelajaran Pendidikan kewarganegaraan (PKN) tingkat keberhasilannya 55\% atau dari 20 siswa, ada 11 siswa yang mendapat nilai di atas KKM (Kriteria Ketuntasan Minimal). Sedangkan KKM (Kriteria Ketuntasan Minimal) Mata Pelajaran Pendidikan kewarganegaraan (PKN) yang telah ditetapkan pada awal tahun pelajaran adalah 65. Dari hasil data itu maka secara klasikal tingkat keberhasilan siswa belum tuntas karena prosentase keberhasilan siswa masih dibawah 70\%. Keberhasilan dalam kegiatan belajar mengajar merupakan harapan bagi semua guru. 
Dari hasil yang diperoleh peneliti dalam ulangan yang dilaksanakan masih kurang berhasil. Maka peneliti perlu melakukan Penelitian Tindakan Kelas (PTK) untuk memperbaiki pembelajaran dan meningkatkan kemampuan penguasaan materi dengan judul "Penerapan Metode Studi Lapangan Dengan Lingkungan Sebagai Sumber Balajar Untuk Meningkatkan Hasil Belajar Pkn Pokok Bahasan Memahami Kebebasan Berorganisasi Pada Kelas V SDN 2 Duwet”.

\section{METODE PENELITIAN}

\section{Jenis Penelitian}

Penelitian ini termasuk jenis Penelitian Tindakan Kelas (PTK) yang menggunakan metode deskriptif kualitatif. Penelitian tidakan kelas ini dilakukan di kelas peneliti yaitu siswa kelas siswa kelas V SDN 2 Duwet Kecamatan Panarukan dengan tujuan untuk memperbaiki atau meningkathasil belajar siswa. Penelitian Tindakan Kelas (PTK) adalah penelitian yang dilakukan oleh guru di kelas atau di sekolah tempat ia mengajar dengan penekanan pada penyempurnaan atau peningkatan proses dan hasil pembelajaran (Arikunto,2010:135). Pengertian Deskriptif Kualitatif yaitu suatu prosedur penelitian yang menggunakan data deskriptif berupa kata-kata tertulis atau lisan dari orang-orang dan pelaku yang dapat diamati. Pendekatan kualitatif, yaitu suatu prosedur penelitian yang menghasilkan data deskriptif berupa ucapan atau tulisan dan perilaku yang dapat diamati dari subyek itu sendiri.

\section{Subjek Penelitian}

Tindakan perbaikan pembelajaran ini dilakukan dalam mata pelajaran Ilmu Pengetahuan Sosial, khususnya dalam materi pokok pembelajaran tentang Memahami Kebebasan Berorganisasi. Tempat pelaksanaan di kelas V SDN 2 Duwet. Pelaksanaan perbaikan mata pelajaran PKN tanggal 4 Mei 2020 Siklus I, tanggal 11 Mei 2020 Siklus II. Inilah siswa kelas V SDN 2 Duwet Kecamatan Panarukan berjumlah 20 orang. Adapun karakteristik siswa kelas V SDN 2 Duwet Kecamatan Panarukan ada :

1. Jumlah siswa 20 orang. 13 orang siswa perempuan dan 7 siswa laki-laki;

2. Tingkat kecerdasan siswa relatif sama, tidak ada yang memiliki keistimewaan dan keluarbiasaan;

3. Fasilitas penunjang kurang memadai (buku,alat,peraga media pembelajaran dan lain-lain);

4. Rata-rata ekonomi wali murid dari ekonomi menengah ke bawah dengan pekerjaan buruh tani dan nelayan;

5. Tenaga pengajar yang masih kurang sehingga setiap guru harus mengajar dua kelas

\section{Desain Penelitian}

Menurut Arikunto, dkk (2010 : 16) ada beberapa ahli yang mengemukakan model penelitian tindakan dengan bagan yang berbeda, namun secara garis besar terdapat empat 
tahapan yang lazim, yaitu: Perencanaan (Planning), Pelaksanaan (Acting), Pengamatan (Observating), dan Refleksi (Reflecting).

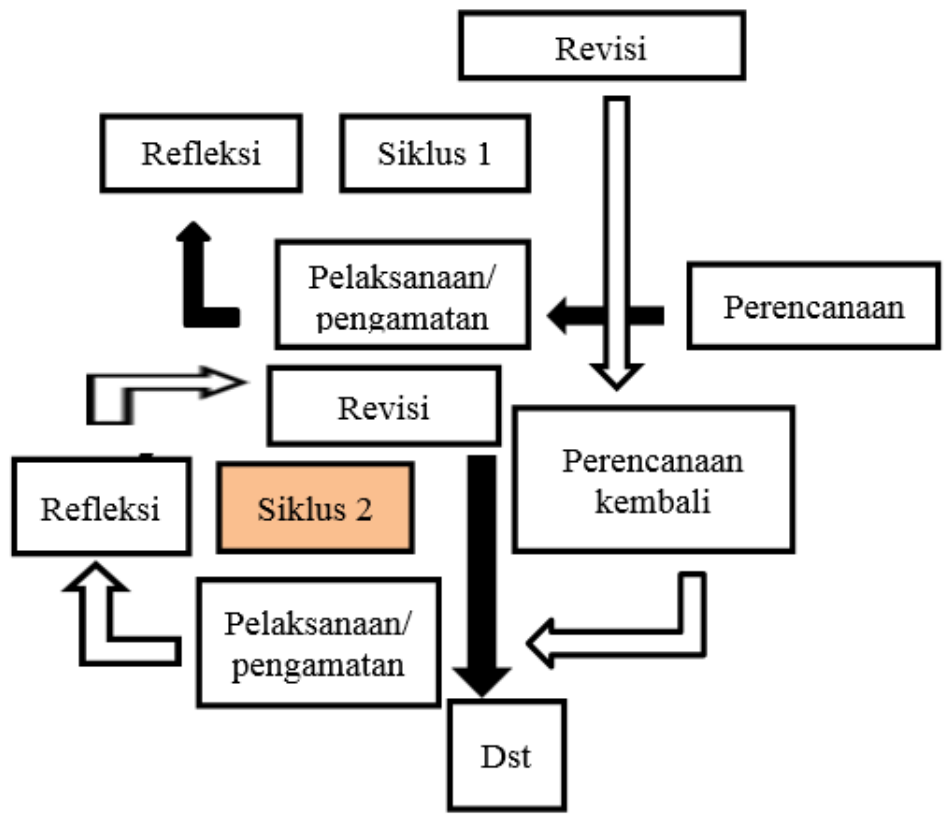

Gambar 1. Bagan Siklus Tindakan Adaptasi model Kemmis dan Taggart (dalam Arikunto:1998)

Penelitian ini dilakukan sebanyak 3 siklus. Tiap putaran siklus dilakukan kegiatan perencanaan,pelaksanaan/pengamatan, refleksi, dan revisi.Teknik pengumpulan data dilakukan melalui observasi, catatan lapangan, dan tes. Observasi dilakukan siswa selama penelitian dengan menggunakan lembar pengamatan siswa. Lembar pengamatan digunakan untuk mencatat semua aktivitas yang dilakukan murid selama penelitian berlangsung, dan hasilnya adalah berupa data hasil keterlaksanaan aspek pembelajaran di kelas V SDN 2 Duwet.

\section{Deskripsi Per Siklus}

Berdasarkan permasalahan yang dihadapi peneliti dibantu oleh teman sejawat maka peneliti melaksanakan perbaikan pembelajaran.

\section{a. Siklus I}

1. Perancanaan

Berdasarkan hasil belajar siswa yang dilaksanakan pada pembelajaran sebelumnya, yang dilaksanakan pada tanggal 27 April 2020 hasil belajar siswa kurang memuaskan. Karena penguasaan materi pembelajaran hanya mencapai 55\% keberhasilannya. Peneliti dibantu dengan teman sejawat merencanakan perbaikan pembelajaran siklus I dengan rencana sebagai berikut.

a) Menentukan standar kompetensi, kompetensi dasar dan indikator; 
b) Membuat persiapan perbaikan pembelajaran;

c) Mempersiapkan cara dan alat observasi;

d) Mempersiapkan media dan alat peraga yang sesuai.

2. Implementasi Tindakan

Dari beberapa kendala yang dihadapi oleh peneliti dengan tugas. Adapun langkahlangkah dalam pelaksanaan pembelajaran pada siklus I ini sebagai berikut:

1. Guru dibantu siswa memasang gambar dan berwarna tentang materi pembelajaran di papan tulis;

2. Guru membentuk siswa menjadi beberapa kelompok diskusi;

3. Setiap siswa untuk menganalisa dan mendeskripsikan gambar;

4. Setiap siswa untuk membaca hasil diskusi tentang hasil materi;

5. Guru dan siswa membahas hasil diskusi.

3. Observasi

Pada siklus ini observer benar-benar mengamati kegiatan guru dan siswa didalam pengumpulan tugas saat kegiatan belajar mengajar berlangsung dengan kondisi yang nyaman, aman, strategis dan metode pembelajaran yang tepat serta perhatian dan pengawasan guru yang benar benar terfokus pada satu kelas membuat siswa belajar lebih senang dan antusias mengikuti proses pembelajaran.

4. Analisis dan Refleksi

Setelah proses belajar mengajar pada Siklus I ini selesai, ternyata hasil belajar siswa meningkat. Penggunaan alat peraga, metode, strategi pembelajaran yang tepat serta perhatian guru yang benar benas terfokus pada satu kelas dapat meningkatkan hasil belajar siswa.

Dari hasil tugas yang diberikan peneliti ternyata tingkat keberhasilan siswa mencapai $75 \%$ dari 20 siswa; 15 siswa nilainya diatas KKM dan siswa lainnya masih bawah Kriteria Ketuntasan Minimal (KKM). Oleh karena itu, peneliti dan observer sepakat untuk melanjutkan ke siklus berikutnya sebagai penetapan penguasaan materi pelajaran kepada siswa.

\section{b. Siklus II}

\section{Perencanaan}

Dari hasil pembelajaran pada siklus I, peneliti dan Observer masih ingin memberi pemantapan hasil belajar yang di capai oleh siswanya. Sehingga perlu mengadakan perlu mengadakan siklus II sebagai berikut :

a. Menentukan standar kompetensi, kompetensi dasar dan indikator.

b. Membuat persiapan perbaikan pembelajaran.

c. Mempersiapkan cara dan alat observasi.

d. Mempersiapkan media dan alat peraga yang sesuai.

2. Implementasi tindakan

Pelaksanaan siklus II ini, peneliti dan observer meminta ijin kepada kepala sekplah untuk melaksanakan pembelajaran diluar sekolah ke sebuah koperasi 
usaha yang bergerak di kegiatan simpan pinjam serta di kantor desa Arjasa untuk mengidentifikasi dan menganalisa kegiatan organisasi secara langsung, sehingga dapat memantapkan penguasaan materi pelajaran bagi siswa. Adapun langkahlangkah pembelajaran yang dilaksanakan oleh peneliti adalah sebagai berikut :

a) Siswa diajak keluar lingkungan sekolah untuk mengidentifikasi kegiatan organisasi di dinas dan KUD.

b) Secara berkelompok dan dengan pengawasan guru siswa mencari contoh tempat-tempat kegiatan keorganisasian sekitar sekolah.

c) Siswa diajak kembali ke kelas dan secara bergantian membaca hasil observasi yang diperoleh tentang kegiatan studi lapangan tersebut.

d) Guru dan siswa menarik kesimpulan dari hasil observasi siswa.

3. Observasi

Pada siklus II ini guru dan siswa melaksanakan pembelajaran di luar kelas. Supaya siswa dapat melaksanakan keorganisasian sekitar sekolah serta dapat menyebutkan jenis jenis badan atau lembaga di sekitar lingkungan sekolah sehingga siswa lebih memahami dari materi yang diterimanya.

Pada siklus ini siswa merasa senang dan antusias mengikuti proses pembelajaran karena mereka dapat secara langsung mengalami kegiatan keorganisasian yang ada di KUD dan Kantor Desa seperti materi yang mereka terima.

4. Analisis dan Refleksi.

Setelah siklus II dilaksanakan dan dievaluasi ternyata hasil belajar siswa meningkat secara signifikan. Karena siswa dapat melaksanakan kegiatan pembelajaran secara langsung sesuai dengan materi yang diterima dan hasil yang dicapai yaitu $90 \%$ dari 20 siswa yang mendapat nilai diatas rata-rata 18 siswa yang mendapat nilai dibawah rata-rata 2 siswa. Sehingga peneliti dan observer memutuskan untuk menyelesaikan perbaikan pembelajaran pada siklus II saja.

\section{HASIL DAN PEMBAHASAN}

\section{Hasil Siklus I}

Pelaksanaan siklus ini direncanakan peneliti dan observer setelah melihat hasil pembelajaran sebelumnya yang hanya mencapai 55\% tingkat keberhasilan. Siklus ini dilaksanakan pada tanggal 4 Mei 2020. Setelah dilaksanakan dan diamati oleh observer ternyata hasil belajar siswa cukup baik yaitu 75\%. Hal ini karena kondisi kelas yang memungkinkan yang membuat siswa lebih tenang dan aman belajar serta perhatian guru yang benar-benar terfokus pada kelas V SDN 2 Duwet, Sehingga perhatian dan pprespon siswa terhadap pembelajaran begitu besar.

Pada siklus I ini guru sudah mampu membuat pembelajaran lebih menarik dan penuh wawasan. Pendekatan studi lapangan sangat memberikan motivasi dalam belajar dan memahami materi secara gamblang. Siswa yang melakukan kegiatan studi lapangan 
dengan meninjau beberapa tempat di sekitar sekolah merasa ada informasi dan pengetahuan sehingga pada tes ulangan pertama dari $55 \%$ siswa yang tidak mencapai KKM tapi pada siklus II sudah naik menjadi $75 \%$.

\section{Hasil Siklus II}

Sebagai pemantapan pada siklus I yang tingkat keberhasilan belajar siswa telah mencapai $75 \%$, maka penelitimelaksanakan proses pembelajaran dengan pemantapan dari siklus I yang dilaksanakan diluar kelas dan siswa diajak langsung melaksanakan kegiatan jual beli. Pada siklus ini antusias dan respon siswa sangatlah tinggi untuk mengikuti pembelajaran. Kegiatan jual beli yang terdapat di pasar sangat membuat anakanak senang untuk melihat dan mempraktekannya. Pasar yang paling dekat adalah MTS di Mangaran dan pecinan di dekat SDN 2 Duwet. Proses studi lapangan di sekolah sangat disukai oleh para siswa-siswa karena mereka mampu menerapkan semua informasi dan ilmu yang di dapat di buku dengan kenyataan yang ada di lapangan. Pada tes ulangan ke II ini siswa kelas V 2 Duwet sebanyak 20 siswa mengikuti ulangan, adapun hasil yang diperoleh cukup memuaskan yaitu $90 \%$ siswa atau sebanyak 18 siswa sudah mendapat nilai diatas KKM.

\section{Pembahasan Hasil Penelitian Siklus I}

Menurut hasil analisis dan interpretasi peneliti yang didasarkan pada hasil pengamatan yang dilakukan oleh teman sejawat sebagai observer, tindakan pembelajaran yang sudah dilaksanakan pada siklus I hasil belajar siswa sudah mengalami peningkatan dari 50\% siswa yang mendapat nilai dibawah KKM, setelah dilaksanakan siklus I ternyata siswa memperoleh nilai diatas KKM sudah mencapai 75\% dari 20 siswa , 15 siswa nilainya diatas KKM dan 5 siswa lainnya masih dibawah KKM. Dengan kesepakatan peneliti dan observer sepakat untuk melanjutkan ke siklus berikutnya sebagai pemantapan penguasan materi pelajaran kepada siswa sebagai alasan, yaitu :

Dari hasil pengamatan perilaku guru dalam mengajar selama berlangsungnya siklus I ternyata guru belum memanfaatkan sumber belajar dengan optimal. Maksudnya, untuk memberikan pemahaman dan pengalaman yang lebih kongkrit kepada siswa dengan siswa dibawah langsung kepada sumber belajar (KUD dan Kantor desa ) di sekitar sekolah sebagai kegiatan organisasi. Atas dasar pemikiran itulah, maka secara refleksi peneliti memutuskan untuk melaksanakan tindakan perbaikan pada siklus II sebagai upaya untuk memberikan pemahaman dan pemantapan kepada siswa terhadap kegiatan jual beli. Fokus utama ditekankan pada pemanfaatan lingkungan sekolah sebagai sumber belajar. Adapun harapan yang ingin dicapai adalah jumlah siswa yang memperoleh nilai minimal 70 sesuai dengan KKM mata pelajaran PKN diupayakan lebih meningkatkan lagi dan pemahaman siswa terhadap topik kegiatan Organisasi lebih kongkrit. 


\section{Pembahasan Hasil Penelitian Siklus II}

Dari hasil penelitia refleksi pada siklus I sebagai upaya memantapkan pemahaman siswa dengan pengalaman yang lebih kongrit serta upaya lebih meningkatkan lagi hasil belajar siswa yang maksimal. Aspek yang perlu ditambah sebagai upaya memantapkan pemahaman siswa yaitu: dengan membawa siswa ke sekolah MTS terdekat yang sudah memiliki wadah OSIS sebagai wadah organisasi siswa didekat sekolah sebagai sumber belajar sehingga siswa memperoleh pengalaman langsung tentang kegiatan keorganisasian untuk melengkapi dan memberikan pemantapan dalam pelaksanaan tindakan perbaikan pembelajaran pada siklus II ini.

Analisis dan interpretasi terhadap hasil yang telah dicapai selama pelaksanaan perbaikan pembelajaran siklus II membawa peneliti kepada beberapa kesimpulan yaitu : a. Hasil belajar siswa kelas V SDN 2 Duwet dari 20 siswa, siswa yang mendapat nilai diatas KKM berjumlah 18 orang (90\%) sesudah dilaksanakan tindakan perbaikan pembelajaran siklus II maka hasil belajar siswa pada siklus II ini sudah melampaui standar minimal ketuntasan klasikal yaitu $70 \%$.

b. Hasil pengamatan terhadap perilaku mengajar guru selama pemantapan pada siklus II. Penggunaan lingkungan sekolah sebagai sumber belajar sudah maksimal.

Hasil analisis dan interpretasi terhadap hasil yang diperoleh selama kegiatan pemantapan pada siklus II. Tujuan diharapkan dari pelaksanaan pemantapan sudah tercapai maksimal. Maka peneliti bersama observer untuk memutuskan bahwa proses penelitian tindakan kelas dan pemantapannya dianggap selesai.

\section{KESIMPULAN DAN SARAN Kesimpulan}

Penelitian Tindakan Kelas sangatlah penting untuk perbaikan pembelajaran. Maka dari hasil perbaikan pembelajaran yang telah dilaksanakan oleh peneliti dapat ditarik beberapa kesimpulan sebagai berikut :

1. Penggunaan metode belajar yang tepat dapat meningkatkan pemahaman dan hasil belajar siswa;

2. Penggunaan metode pembelajaran yang cukup dan sesuai dengan materi dapat meningkatkan hasil belajar yang maksimal;

a) Keratifitas dan pengetahuan guru yang baik dapat meningkatkan kelancaran proses belajar mengajar dan meningkatkan hasil belajar;

b) Kondisi kelas yang tenang dan nyaman serta perhatian guru yang maksimal dapat membantu meningkatkan hasil belajar siswa;

c) Pemberian tugas/soal-soal secara rutin dapat meningkatkan pemahaman dan kemampuan siswa.

d) Pemanfaatan lingkungan sekolah sebagai sumber belajar dapat memberikan pemahaman yang kongrit dan meningkatkan hasil belajar siswa. 


\section{Saran}

Berdasarkan kesimpulan tersebut, beberapa hal yang yang sebaiknya dilakukan oleh guru dalam meningkatkan kualitas pembelajaran di kelas adalah sebagai berikut :

1. Mempersiapkan metode pembelajaran yang tepat dalam setiap proses belajar mengajar;

2. Setiap proses belajar mengajar sebaiknya guru mempersiapkan media pembelajaran dengan matang;

3. Sebaiknya harus benar-benar menguasai materi dan memiliki keterampilan yang baik dari setiap mata pelajaran;

4. Guru harus dapat mengelola kelas dengan baik;

5. Memberikan soal/tugas kepada siswa yang jelas dan dilakukan secara rutin;

6. Meningkatkan keterampilan dan kemampuan dan keterampilan guru dalam setiap mata pelajaran;

7. Sebaiknya guru memanfaatkan lingkungan sekitar sebagai sumber belajar.

\section{DAFTAR RUJUKAN}

Arikunto. 2010 . Prosedur Penelitian Suatu Pendekatan Praktek. Jakarta: Rieneka Cipta

Hermawan, Asep Harry (2006). Media dan Proses Pembelajaran, Jakarta: Universitas Terbuka

Sadiman, Arief S. (1986). Media Pendidikan : Pengertian, Pengembangan dan Pemanfaatan. Jakarta: CV. Rajawali

Roestiyah, NK. (1986). Masalah-masalah Ilmu Keguruan, Bandung: Bina Aksara

Ed. Minor and Harvey R. Frye. (1977). Techniques for Produsing Visual Instructional Media. Second EditionNew York. McGrow-Hill Book Company

Sudjarwo. S, (Ed). (1989). Beberapa Aspek pengembangan Sumber Belajar. Jakarta. Medyatama Sarana Perkasa

Sri Anitah W: DKK (2007). Strategi pembelajaran di SD. Jakarta: Universitas Terbuka Wardhani, I.G.A.K ; Wihardit, K: Nasoetion, N (2000). Penelitian Tindakan Kelas, Jakarta: Universitas Terbuka 
Volume 4, Nomor 2, Agustus 2020 